\title{
Green (Detox) juice physicochemical properties and stabilization effect of naturals emulsifiers
}

\author{
Jully Lacerda Fraga ${ }^{*}\left(\mathbb{C}\right.$ Gizele Cardoso Fontes Sant'Ana ${ }^{2}(\mathbb{D}$ \\ Kelly Alencar Silva ${ }^{3} @$ Priscilla Filomena Fonseca Amaral ${ }^{1} \odot$
}

'Departamento de Engenharia Bioquímica, Escola de Química, Universidade Federal do Rio de Janeiro (UFRJ), 21949-900, Rio de Janeiro, RJ, Brazil. E-mail: jully.lfraga@gmail.com. .Corresponding author.

${ }^{2}$ Departamento de Tecnologia de Processos Bioquímicos, Instituto de Química, Universidade do Estado do Rio de Janeiro (UERJ), Rio de Janeiro, RJ, Brazil.

${ }^{3}$ Centro de Ciências Médicas, Faculdade de Farmácia, Universidade Federal Fluminense (UFF), Niterói, RJ, Brasil.

ABSTRACT: Green or "detox" juice is a mixture of fruit juice with vegetables, which has been used intensively by consumers seeking for healthy food. Physicochemical properties of Green juice were accessed in the present research, which brings new insights for the use of this beverage in human diet. A total phenolic content of $2833.60 \mathrm{mg} \mathrm{GAE} \mathrm{(Gallic} \mathrm{acid} \mathrm{equivalent)/g} \mathrm{of} \mathrm{juice} \mathrm{and} \mathrm{a} \mathrm{Total} \mathrm{Antioxidant} \mathrm{Capacity} \mathrm{by}$ FRAP of $323.62 \mu \mathrm{MFe}_{2} \mathrm{SO}_{4} / \mathrm{g}$ of juice and by $\mathrm{ABTS}^{\circ+}$ of $333.11 \mu \mathrm{M}$ Trolox/g of juice, indicated good antioxidant properties. Low energy and reducing sugar content indicate its use for low calorie diet, but low carbohydrate and protein content prove that Green juice cannot be used as meal replacement. The addition of a microbial biosurfactant (YlBio) and chia gel as bioemulsifiers was tested in the Green juice formulation to reduce solid decantation and increase consistency. YlBio and chia gel were able to change the Newtonian behavior of the Green juice to a Pseudoplastic behavior due to stabilization properties and also increase consistency, without the need to add synthetic stabilizers.

Key words: Yarrowia lipolytica, chia seed mucilage, food rheology, pseudoplastic fluid, bioemulsifiers.

Propriedades físico-químicas do suco verde (detox) e efeito de estabilização de emulsificantes naturais

RESUMO: O suco verde ou "detox" é uma mistura de suco de frutas com vegetais que tem sido intensamente utilizado por consumidores que buscam alimentos saudáveis. As propriedades fisico-químicas do suco verde foram avaliadas no presente trabalho, o que traz novas perspectivas para o uso dessa bebida na dieta humana. Um conteúdo fenólico total de 2833,60 mg de EAG (equivalente em ácido gálico) / $\mathrm{g}$ de suco) e uma capacidade antioxidante total por FRAP de 323,62 $\mu \mathrm{M}$ de $\mathrm{Fe}_{2} \mathrm{SO}_{4} / \mathrm{g}$ de suco e por ABTS ${ }^{\circ+}$ de 333,11 $\mu \mathrm{M}$ de Trolox / g de suco, indicam boas propriedades antioxidantes. Um baixo teor de energia e açúcar redutor indica seu uso em dietas de baixa caloria, mas o baixo teor de carboidratos e proteinas prova que o suco verde não pode ser usado como substituto de refeição. A adição de um biossurfactante microbiano (YlBio) e do gel de chia no suco foi testada na formulação do suco verde, para reduzir a decantação de sólidos e aumentar a consistencia. YlBio e o gel de chia foram capazes de mudar o comportamento do suco de fluido Newtoniano para um fluido pseudoplástico devido às propriedades estabilizantes, e também aumentaram a consistência do suco, sem a necessidade de adição de estabilizantes sintéticos. Palavras-chave: Yarrowia lipolytica, mucilage de semente de chia, reologia de alimentos, fluidos pseudoplásticos, bioemulsificantes.

\section{INTRODUCTION}

Green (detox) juices have become a popular drink since it has been associated to healthy aspects. This is consistent with the composition of those juices: at least one of the ingredients is a vegetable and it usually also contains fruits. Therefore, they may be a source of vitamins and energy (SCHEFFERS, et al., 2019; ZULUETA et al., 2007). However, knowledge about the properties of these juices is still scarce in literature. It is supposed to have healthy aspects because the consumption of fruits and vegetables are commonly related to the decrease in cancer risk, aging-related and coronary diseases (HALLIWELL \& GUTTERIDGE, 1995;
HENNEKENS, 1994). Commercial formulations of these green juices are reported in markets because with the daily activities the time to prepare food is insufficient, increasing the consumer preference for processed foods (ROMANO et al., 2015).

For a better consumer acceptance of functional food, it is important to use natural additives in its composition (GRUNERT, 2010). The use of additives from natural sources like plants and seeds or GRAS (Generally Recognized as Safe) microorganisms' products is very appealing for the consumer's choice. The great advantage of bioemulsifiers produced by yeasts is the GRAS status of some of these microorganisms, such as Yarrowia lipolytica, Saccharomyces cerevisiae and Kluyveromyces lactis (BARTH \& GAILLARDIN, 1997). 
Biosurfactants are amphiphilic compounds produced by living organisms, mostly on microbial cell surfaces or in the extracellular medium, that reduce surface tension and interfacial tension at the surface and interface, respectively. The reason for its popularity is the specific action, low toxicity, high biodegradability, effectiveness in extreme conditions and unique structures of these compounds (MUTHUSAMY et al., 2012). The biosurfactant produced by Yarrowia lipolytica IMUFRJ 50682 was characterized as a proteinpolysaccharide complex with a small percent of fat acids able to stabilize oil-in-water emulsions (Amaral et al., 2006; Trindade et al., 2008). Biosurfactants can be used in juices to interact with hydrophobic compounds, solving a common problem, which is the decantation of components that results in a heterogeneous appearance, decreasing its value.

The seeds of the species Salvia hispanica L. commonly known as "chia" are native to the region that extends from the North of Mexico to Guatemala. It has been evaluated for food enrichment because of its properties (COELHO, \& SALAS-MELLADO, 2015). When immersed in water, chia seeds forms gel, that represents 5 to $6 \%(\mathrm{w} / \mathrm{w})$ of its material and it's mainly composed of carbohydrates responsible for water retention. This gel, named chia mucilage, can be useful as a bioemulsifier or surfactant on aqueous solutions (MUÑOZ et al., 2012). Chia mucilage can be used as a natural thickener that can give drinks, such as green juice, a better appearance because it interacts with particles that are dispersed in the suspension conferring stability.

Although, there is a great demand for fruit functional beverages, there is a lack of information about the nutritional value and the real antioxidant capacities of "Detox" or "Green" juices, widely sold all over the world. Therefore, in this research a Green juice formulation was tested, and its properties were evaluated. In order to promote the stability of this Green juice, chia seed gel and Yarrowia lipolytica's biosurfactant (YlBio), two natural bioemulsifiers, were evaluated.

\section{MATERIALS AND METHODS}

\section{Green (Detox) juice components}

Pineapple (Ananas comosus L.), carrot

(Daucus carota), selecta sweet orange (Citrus sinensis L.), kale (Brassica oleracea), mint (Mentha s.p.), ginger (Zingiber officinale) and cucumber (Cucumis sativus) were bought at local supermarket (Nova Iguaçu, Rio de Janeiro, Brazil). A commercial
Brazilian detox juice (Total Detox ${ }^{\circledR}$ - Vitadrink lemon flavor) was used as comparison.

\section{Biosurfactant production}

Biosurfactant was produced with cashew apple juice as carbon source during cultivation of Yarrowia lipolytica according FONTES et al. (2012). After $72 \mathrm{~h}$ of fermentation, the yeast cells were harvested by centrifugation and the cell free medium was submitted to a liquid-liquid extraction with chloroform and methanol. The white powder obtained after lyophilization was used as biosurfactant, herein called $Y l$ Bio.

\section{Chia gel production}

The chia gel was prepared with chia seeds (Salvia hispânica L.) (Louro Verde - Rio de Janeiro, Brazil). One milligram of chia seed was mixed with $30 \mathrm{~mL}$ of water at $25{ }^{\circ} \mathrm{C}$, with a magnetic stirrer for $2 \mathrm{~h}$. The seeds were separated of chia gel by centrifugation $(3000 \mathrm{~g}, 30 \mathrm{~min})$. The gel was frozen at $-50{ }^{\circ} \mathrm{C}$ and lyophilized (Terroni modelo Enterprise 2). This method was adapted from SPADA et al. (2014).

\section{Green juice preparation}

For the green juice preparation all the components were washed, sanitized with hypochlorite $2 \%$, processed by blender (Philips RI2160 191/BB - Ser 1444) and filtered in a culinary sieve. The first formulation tested contained 416.70 $\mathrm{g}$ of pineapple (Ananas comosus L.), $0.70 \mathrm{~g}$ of carrot (Daucus carota), $200 \mathrm{~mL}$ of filtered water, $30.69 \mathrm{~g}$ of kale (Brassica oleracea) and $182.51 \mathrm{~g}$ of cucumber (Cucumis sativus). The second formulation was similar to the first, but without carrot. The final formulation contained $225.05 \mathrm{~g}$ of Selecta sweet orange juice (Citrus sinensis L.), $200 \mathrm{~mL}$ of filtered water, $30.69 \mathrm{~g}$ of kale (Brassica oleracea), 3.97 $\mathrm{g}$ of mint (Mentha s.p.), $0.77 \mathrm{~g}$ of ginger (Zingiber officinale) and $182.51 \mathrm{~g}$ of cucumber (Cucumis sativus). The efficiency of Green juice production was calculated after the filtration. For the antioxidant capacity and total phenolic content determination, the juice was prepared just before the analysis. For the other physicochemical assays and proximate composition, the juice was frozen in amber flask at $-18{ }^{\circ} \mathrm{C}$ after preparation and defrosted at the time of the analysis.

\section{Green juice formulation}

The green juice formulation used in the present research was chosen after a screening of 25 recipes of Detox or Green juice from the internet, 
considering the price, nutritional value on literature and the components processing procedure (data not shown). Three formulations were chosen after this evaluation. One of these formulations, Green juice 1 , consisted of pineapple juice, carrot, kale and cucumber. This juice formulation was also tested with a filtration process after preparation. Green juice 2 , consisted of pineapple juice, kale and cucumber and was also filtered. Green juice 3, which was also filtered after preparation, was prepared with: orange juice, kale, mint, ginger and cucumber. A commercial Brazilian detox juice (Total Detox ${ }^{\circledR}-$ Vitadrink lemon flavor) was used as comparison.

\section{Physicochemical analysis}

Total titratable acidity, total soluble solids (TSS) were determined by a refractometer (K52032-Kasvi $\left.{ }^{\circledR}\right)$, Soluble solids $\left({ }^{\circ} \mathrm{Brix}\right)$ and $\mathrm{pH}$ were measured at $19{ }^{\circ} \mathrm{C}$ using a refractometer (K52-032$\mathrm{Kasvi}^{\circledR}$ ) (Bellingham-Stanley Ltd., London, England) and a $\mathrm{pH}$ meter (Marte model MB10 pH meter), respectively. The titratable acidity of the juice was measured using a Phenolphthalein Indicator Solution and the juice was titrated against $0.1 \mathrm{NaOH}$ until the endpoint of $\mathrm{pH} 8.1$ and expressed as " $\mathrm{g}$ citric acid/100 $\mathrm{mL}$ orange juice" $(\%$ acid $=[$ mols $\mathrm{NaOH}$ used $] \times[0.1$ $\mathrm{N} \mathrm{NaOH}$ ] x [milliequivalent factor] $\mathrm{x}$ [100]/ $\mathrm{g}$ of sample) (A.O.A.C, 2012).

\section{Proximate composition}

For proximate composition of the Green juice, protein content (total nitrogen) was quantified by Kjeldahl method and moisture, total solids, ashes by Adolf Lutz Institute (1985) method. The fat content was quantified by Bligh and Dyer (BLIGH \& DYER, 1959). Carbohydrate content was calculated by subtracting humidity rate, ashes, protein and lipid from a $100 \mathrm{~g}$ sample. Total Energetic Value was calculated based on Atawer conversion factors, which considers $4 \mathrm{kcal} / \mathrm{g}$ of protein, $4 \mathrm{kcal} / \mathrm{g}$ of carbohydrate and $9 \mathrm{kcal} / \mathrm{g}$ of lipid (FAO, 2003).

\section{Quantification of the total phenolic content (TPC)}

Total Phenolic Content (TPC) of the nonfiltered pure green juice, green juice with chia gel $(0.05 \mathrm{mg} / \mathrm{mg}$ of juice) and Green juice with $Y l \mathrm{Bio}$ $(0.05 \mathrm{mg} / \mathrm{mg}$ of juice $)$ were determined by FolinCiocalteu method with modifications (BONOLI, 2004). The extraction was performed with $10 \mathrm{~mL}$ methanol solution $50 \%(\mathrm{v} / \mathrm{v})$ and $0.5 \mathrm{mg}$ of Green juice. All the extracts were centrifuged and the supernatants were reserved. An aliquot of $0.1 \mathrm{~mL}$ of the extract and $6 \mathrm{~mL}$ of distilled water were mixed with $500 \mu \mathrm{L}$ of Folin - Ciocalteu reagent (Vetec - Rio de Janeiro Brazil) and $2 \mathrm{~mL}$ of $15 \%$ sodium carbonate solution $(\mathrm{v} / \mathrm{w})$ in a glass tube. The tubes were stirred and then $1.4 \mathrm{~mL}$ of distilled water was added. The tubes were stirred and, after 2 hours, the absorbance was measured in a spectrophotometer at $750 \mathrm{~nm}$. The result was expressed in mg. $100 \mathrm{~g}^{-1}$ of Gallic Acid Equivalent (GAE) (WAIN \& HILLS, 1995).

\section{Antioxidant activity by FRAP and ABTS ${ }^{\circ+}$}

Total antioxidant capacity was quantified by FRAP (Ferric Reducing Antioxidant Power) (RUFINO et al., 2010) and ABTS ${ }^{\cdot+}$ (2,2'-Azinobis[3-ethylbenzthiazoline-6-sulfonic] acid) assay as described by Kuskoski et al, (2005).

For FRAP, stock solutions were prepared: $0.3 \mathrm{M}$ acetate buffer $\left(3.1 \mathrm{~g} \mathrm{C}_{2} \mathrm{H}_{3} \mathrm{NaO}_{2} \cdot 3 \mathrm{H}_{2} \mathrm{O}\right.$ and $\left.16 \mathrm{~mL} \mathrm{C}_{2} \mathrm{H}_{4} \mathrm{O}_{2}\right), \mathrm{pH} 3.6,10 \mathrm{mM}$ TPTZ (2, 4, 6-tripyridyl-s-triazine) solution in $40 \mathrm{mM} \mathrm{HCl}$, and $20 \mathrm{mM} \mathrm{FeCl} \cdot 6 \mathrm{H}_{2} \mathrm{O}$ solution. The FRAP solution was prepared by mixing $25 \mathrm{~mL}$ acetate buffer $0.3 \mathrm{M}, 2.5$ $\mathrm{mL}$ TPTZ (2, 4, 6-tripyridyl-s-triazine) $10 \mathrm{mM}$ (in $40 \mathrm{mM} \mathrm{HCl}$ ), and $2.5 \mathrm{~mL} \mathrm{FeCl} \cdot 6 \mathrm{H}_{2} \mathrm{O} 20 \mathrm{mM}$ and then warmed at $37^{\circ} \mathrm{C}$. Green juice with and without bioemulsifiers ( $2 \mathrm{mg} / \mathrm{mL}$ of juice) were vortexed with $2.7 \mathrm{~mL}$ of the FRAP solution incubated at $37^{\circ} \mathrm{C}$ for $30 \mathrm{~min}$ in the dark. Readings of the colored product [ferrous tripyridyltriazine complex] were then taken at $595 \mathrm{~nm}$. Results are expressed in $\mu \mathrm{M} \mathrm{Fe}_{2} \mathrm{SO}_{4} / \mathrm{g}$ of juice (Pulido, et al., 2010).

The $\mathrm{ABTS}^{\cdot+}$ radical cation solution $(2.45$ $\mu \mathrm{M})$ was prepared by reacting $5 \mathrm{~mL}$ ABTS solution ( $7 \mathrm{mM}$ ) with $88 \mathrm{~mL}$ of $\mathrm{K}_{2} \mathrm{~S}_{2} \mathrm{O}_{8}$ solution for $16 \mathrm{~h}$ in the dark at room cooled temperature $\left(25^{\circ} \mathrm{C}\right)$. A calibration curve was prepared using a Trolox (6-hydroxy2,5,7,8-tetramethylchroman-2-carboxylic acid) standard solution $(2.000 \mu \mathrm{M})$. Antioxidant activity was expressed as trolox equivalent antioxidant capacity, $\mu \mathrm{mol}$ TEAC/ g FW.

\section{Stability of the green juice}

To evaluate the emulsion stability of the Green juice, decantation index (D.I.) was determined with the methodology of FONTES et al. (2012). Three 3 different emulsifiers were used in this test: Xanthan gum (Rhodia ${ }^{\circledR}$ ) used in commercial Detox juice, standard for visual comparison, $Y l$ Bio and chia gel. The concentrations of bioemulsifiers evaluated in this study were chosen based in their critical micelle concentration $(0.5 \mathrm{mg} / \mathrm{mL}$, for $Y$. lipolytica and 0.3 $\mathrm{mg} / \mathrm{mL}$ for xanthan gum) (AMARAL et al., 2006). Chia gel was tested with 1,2 and $3 \mathrm{mg} / \mathrm{mL}$, while for xanthan gum and $Y l B i o 0.5,0.7$ and $1 \mathrm{mg} / \mathrm{mL}$ 
were used. The bioemulsifiers were solubilized in 10 $\mathrm{mL}$ of Green juice by vortex mixing for 5 minutes in glass tubes. Then, the glass tubes were left to stand still for $24 \mathrm{~h}$ at $8^{\circ} \mathrm{C}$. After this period, the emulsion size was measured vertically. The D.I. is given as a percentage of emulsified layer height $(\mathrm{cm})$ divided by total height of the liquid column $(\mathrm{cm})$. The higher this value, the higher is the stability of the juice. The variance was calculated by ANOVA test using a level of significance of $\mathrm{P}<0.05$.

\section{Rheological characterization}

The rheological behavior of Green juice with and without bioemulsifiers (chia gel, YlBio) was determined as described by VANDRESEN et al (2009) using a rotational viscometer equipped with concentric cylinders (ARG2 - Instrument Control AR), coupled to a thermostatically controlled bath (Julabo F25) at $25^{\circ} \mathrm{C}$. The rheological analysis was carried out varying the shear rate from 0 to $1000 \mathrm{~s}^{-1}$ (ascending curve) and from 1000 to $0 \mathrm{~s}^{-1}$ (descending curve). The storage (G') and loss modules $\left(G^{\prime \prime}\right)$ were obtained in variable frequency $(0.1 \mathrm{a} 10 \mathrm{~Hz})$ at 25 ${ }^{\circ} \mathrm{C}$. The readings were taken twice, and for each measurement a new sample was used. Rheological data was fitted in Newton, Ostwald-De-Waele, Herschel-Bulkley, Bingham, Mizhari-Berk and Casson models (Vandresen et al., 2009) and the parameters were obtained with Excel $\left(\right.$ Microssoft $^{\circ}$ Office 2010 - USA).

\section{Statistical analysis}

Significant differences between the results were calculated by analysis of variance (ANOVAP $>5$ ). One-way ANOVA was calculated on three triplicate measurements and a post-hoc test was conducted to determine differences among means using Tukey test. Differences at $\mathrm{p}<0.05$ were considered significant. All statistical analyses were performed using Excel (Microsoft $^{\circ}$ Office 2010 - USA).

\section{RESULTS AND DISCUSSION}

\section{Chia gel and biosurfactant production}

For Chia gel production $163.76 \mathrm{~g}$ of gel were obtained from $10.0 \mathrm{~g}$ of seed and $300.68 \mathrm{~g}$ of water, resulting a $2 \%$ yield for the lyophilized gel. The appearance of the chia gel was spongy. For the bioemulsifier produced after culturing $Y$. lipolytica in cashew apple juice medium, $2.58 \mathrm{~g}$ of $Y l$ Bio was obtained from $1 \mathrm{~L}$ of fermented medium.

\section{Formulation of green (Detox) juice}

Three different Green juice recipes were tested and the appearance of the prepared juices is shown in figure 1. It was possible to notice (visually and by tasting) that Green juice 1 (Figure. $1 \mathrm{~A}$ ) had a thick consistency that made it difficult to swallow, probably due to the presence of too much fiber. The filtered juice (Figure. 1B) had a better taste and was visually more acceptable as a juice. However, the color was still yellowish, which would not be satisfactory for a future commercial Green juice. This color was certainly due to the presence of carrot. So, we decided to remove that vegetable, obtaining Green juice 2 (Figure. 1C) and also test another formulation (Green juice 3): orange juice, kale, mint, ginger and cucumber (Figure. 1D). These two last juices were visually more acceptable. It is possible to notice that the appearance of the commercial Brazilian detox juice (Total Detox ${ }^{\circledR}$ - Vitadrink - lemon flavor) (Figure. 1E) wasn't natural and green as was expected for a detox juice.

The final formulation of the Green juice was chosen based on organoleptic characteristics (color, flavor and smell) of the juices and it was composed of Selecta sweet orange juice (Citrus sinensis L.), kale (Brassica oleracea), mint (Mentha s.p.), ginger (Zingiber officinale) and cucumber (Cucumis sativus) (Green juice 3). The yield of the Green juice production was $74.73 \%$ relative to nonfilter juice (465.71 g).

\section{Physicochemical and centesimal characterization \\ The Total Titratable Acidity of the Green} juice was reported to be inferior to the acidity found for clarified Royal Gala apple juice (Malus domestica Borkh) (0.237 $0.002 \mathrm{~g} / 100 \mathrm{~g})$ (PIMENTEL et al., 2015) and for orange juice $(0.63 \mathrm{~g} / 100 \mathrm{~g})$ (PINELI et al., 2011). This data indicated that the addition of vegetables and greens can reduce the acidity of the orange juice (Table 1). Total soluble solids were 4.9 ${ }^{\circ}$ Brix for Green juice 3, which was close to values obtained for two different types of strawberry (Fragaria L.) extracts (PALA, \& TOKLUCU, 2013): $7.5^{\circ}$ Brix for the pink Osogrande strawberry and 7.9 ${ }^{\circ}$ Brix for the Camino Real strawberry (Table 1).

The $\mathrm{pH}$ value of the selected Green juice (Table 1) was similar to the $\mathrm{pH}$ of juices of two nectarine's types: 4.23 for Big Top nectarine and 4.24 for Luciana nectarine (Aguilar et al., 2016). In a study about orange juice storage a $\mathrm{pH}$ of 4.06 was reported for the UV-C untreated sample (PALA $\&$ TOKLUCU, 2013). The $\mathrm{pH}$ value of Green juice was closed to the other citric juices. The reducing sugar present in the Green juice (Table 1) was low in comparison to orange juice $(9.0 \pm 0.1 \mathrm{~g} / 100 \mathrm{~mL})$, apple juice $(10.0 \pm 0.1)$ and grape juice $(11.6 \pm 0.1$ 


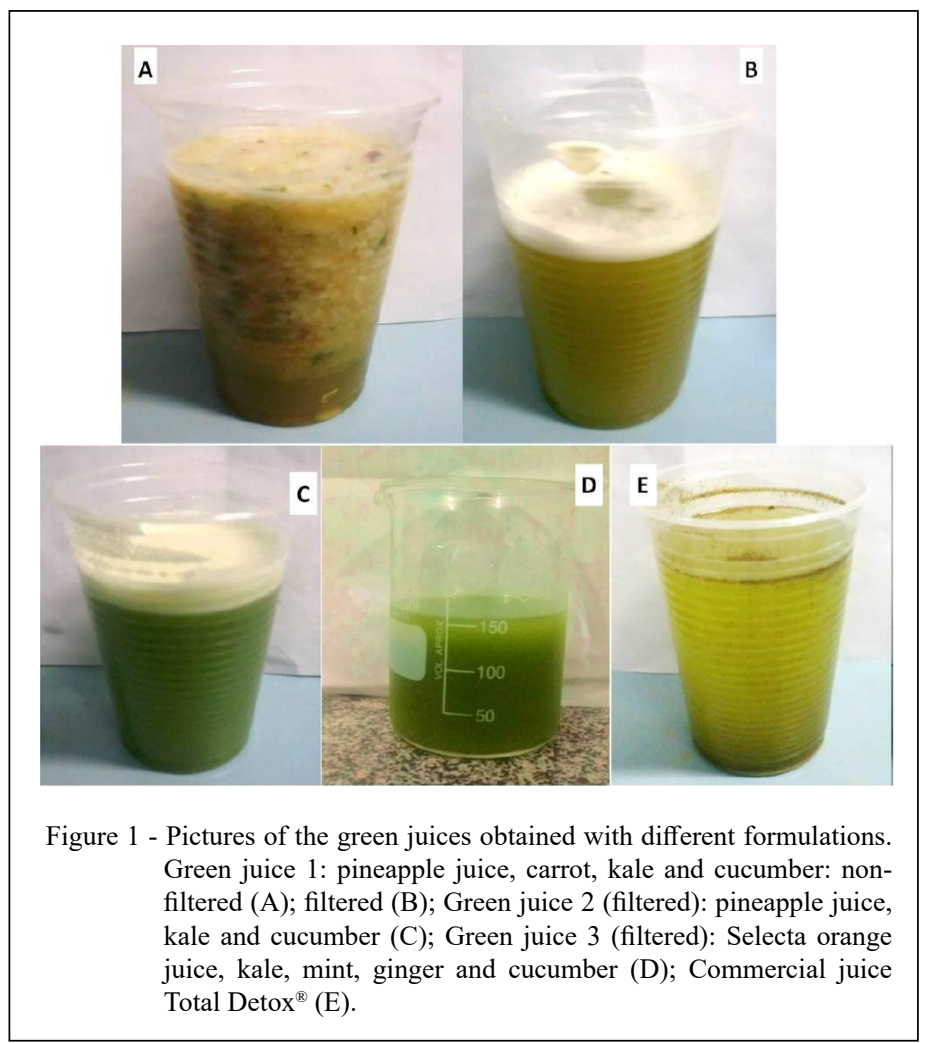

$\mathrm{g} / 100 \mathrm{~mL}$ ) (BAŞKAN et al., 2016). This means that this beverage would be good for people going on a diet with low sugar ingestion.

The energy of Green juice 3 (Table 2) was similar to two types of orange juices: Blood orange and Pera orange (Citrus sinesnis L. Osbeck) (37 and 33 $\mathrm{Kcal} / 100 \mathrm{~g}$, respectively) (NEPA - UNICAMP, 2011), indicating that the addition of other components to the formulation did not increase the energy value. Therefore, the Green juice can be a great alternative for people with restrictive calories diet. The content of carbohydrate, protein and moisture reported for the Green juice was also close to the average of several citric juices (Blood orange, Pera orange, Galego lemon (Citrus aurantifolia) and Rangpur lime) (NEPA - UNICAMP, 2011).

The fat value of Green juice (Table 2) was similar to yellow mombin (Spondias mombin L.) pulp $(0.62 \pm 0.05 \mathrm{~g} / 100 \mathrm{~g})$, but its carbohydrate value $(13.90 \pm 0.04 \mathrm{~g} / 100 \mathrm{~g})$ was higher than the Green juice (Tiburski et al., 2011). Green juice is commonly used as a meal replacement, but these results showed

Table 1 - Physicochemical parameters (Efficiency, Total Titratable Acidity, pH, TSS, Ascorbic Acid Content and reducing sugars) of Green juice 3. Values obtained from triplicates.

\begin{tabular}{lc}
\hline Parameters & Values \\
\hline Efficiency (\%) & 74.73 \\
\hline Total Titratable Acidity (mg Citric Acid/100 mL) & $163.57 \pm 0.01$ \\
\hline $\mathrm{pH}$ & $4.27 \pm 0.01$ \\
Total Soluble Solids $\left({ }^{\circ}\right.$ Brix - g/ 100g) & $4.9 \pm 0.1$ \\
\hline Ascorbic Acid Content (mg/100mL) & $39.68 \pm 0.28$ \\
\hline Reducing Sugars $(\mathrm{g} / \mathrm{L})$ & $12.86 \pm 0.01$ \\
\hline
\end{tabular}

Ciência Rural, v.50, n.3, 2020. 
Table 2 - Proximate composition of Green juice 3.

\begin{tabular}{lccc}
\hline Parameter & Minimum & Maximum & ${\text { Mean } \pm \mathrm{SD}^{\mathrm{a}}}$ \\
\hline Energy $(\mathrm{Kcal} / 100 \mathrm{~g})$ & - & - & 34.6 \\
Carbohydrate $(\mathrm{g} / 100 \mathrm{~g})$ & - & - & 6.68 \\
Protein $(\mathrm{g} / 100 \mathrm{~g})$ & 0.44 & 0.47 & $0.46 \pm 0.03$ \\
Fat $(\mathrm{g} / 100 \mathrm{~g})$ & 0.67 & 0.67 & $0.67 \pm 0.002$ \\
Moisture $(\mathrm{g} / 100 \mathrm{~g})$ & 94.78 & 94.8 & $94.79 \pm 0.01$ \\
Ash $(\mathrm{g} / 100 \mathrm{~g})$ & 0.32 & 0.36 & $0.34 \pm 0.02$ \\
Total Solids $(\mathrm{g} / 100 \mathrm{~g})$ & 5.19 & 5.21 & $5.20 \pm 0.01$ \\
\hline
\end{tabular}

${ }^{\mathrm{a}} \mathrm{SD}$ : standard deviation.

that it's not recommended because despite being nutritive this beverage does not present enough carbohydrates $(130 \mathrm{~g})$ or proteins $(0.66 \mathrm{a} 0.76 \mathrm{~g} / \mathrm{kg}$ of body weight) and others nutrients necessary for healthy men and women on the ages between 7 and 90 years old (TRUMBO, 2002).

\section{Total phenolic compounds (Folin Ciocalteau)}

Total phenolic content was previously performed with a filtered juice, but the data obtained was lower than the quantification limit. The total phenolic content for the lyophilized non-filtered Green juice (GJ) was measured with and without the addition of bioemulsifiers $(0.5 \mathrm{mg} / \mathrm{mg}$ of juice $)$. Values of total phenolic content was 2833.6, 1686.5 and 1933.7 GAE $\backslash 100 \mathrm{~g}$ of Green Juice for Green juice 3 (GJ), GJ with and without bioemulsifier, respectively (Figure 2).

A significant difference $(p<0.05)$ for the total phenolic content was reported between the values of the pure Green juice and the green juice with Chia gel and $Y l$ Bio (Figure 2). The addition of the bioemulsifiers may have damaged the interaction between the extract and the solvent contributing equally $(p>0.05)$ for the lower detection of the phenolic compounds by the Folin Ciocalteau assay. The phenolic content of the Green juice without bioemulsifier was closed to pink (2909.48 $\pm 155.96 \mathrm{mg} \mathrm{GAE} / \mathrm{Kg})$ and ripe strawberry acetone extracts $(2234.62 \pm 69.61$ mg GAE/ Kg) (PINELI et al., 2011). The high value of phenolic content reported in Green juice is a great result because people that consume this beverage search for the benefits for their health. A wide range of biological actions can be expected with phenolic phytochemicals present in Green juice, as the ability to act as antioxidants and to mitigate inflammation, amongst others functions (ARTS, et al., 2005).

\subsection{Total antioxidant capacity: FRAP and ABTS ${ }^{++}$}

For the Total Antioxidant Capacity (TAC) determined by FRAP is possible to observe that the slight increase of TAC value for Green juice with chia gel was not significant (ANOVA $\mathrm{P}>0.5$ ) compared with the others. The values of TAC obtained by FRAP were $323.62 \pm 0.02,328.41 \pm 0.02$ and $322.41 \pm 0.02$ $\mu \mathrm{M} \mathrm{Fe}_{2} \mathrm{SO}_{4} / \mathrm{g}$ of GJ, for GJ with chia gel and GJ with $Y l \mathrm{Bio}$, respectively. Comparing the antioxidant capacity of Green juice with non-conventional Brazilian native fruits extracts (aqueous-organic), it was observed that it is similar to Açaí $\left(220.4 \pm 3.9 \mu \mathrm{M} \mathrm{Fe}_{2} \mathrm{SO}_{4} / \mathrm{g}\right)$ and higher than Umbu (Spondias tuberosa Arruda) $(143 \pm 1.3 \mu \mathrm{M}$ $\mathrm{Fe}_{2} \mathrm{SO}_{4} / \mathrm{g}$ ) extracts (RUFINO et al., 2010).

The $\mathrm{ABTS}^{\cdot+}$ assay showed also that there is no significant difference $(\mathrm{P}>0.5)$ between TAC values for Green juice with and without the bioemulsifiers. Results obtained for FRAP and $\mathrm{ABTS}^{\cdot+}$ for the Green juice were similar, differing very little numerically, ratifying the data obtained in this study. The $\mathrm{ABTS}^{+}$ assay showed also that there is no significant difference $(\mathrm{P}>0.5)$ between TAC values by $\mathrm{ABTS}^{\cdot+}$ for GJ (333.11 $\pm 0.01 \mu \mathrm{M}$ Trolox/g), GJ with chia gel $(332.89 \pm 0.01 \mu \mathrm{M}$ Trolox/g) and with YlBio (340.83 $\pm 0.02 \mu \mathrm{M}$ Trolox/g). The antioxidant capacity of organic-aqueous extract of Açai (Euterpe oleracea) $(64.5 \pm 19.2 \mu \mathrm{M}$ Trolox/g) and Umbu $(77 \pm 15.4 \mu \mathrm{M}$ Trolox/g) (RUFINO et al., 2010), Brazilian native fruits, were inferior to the value observed for the Green juice by the ABTS $^{\cdot+}$ assay. These fruit species are rich in antioxidant compounds and nutrients capable of preventing degenerative diseases. Due to this fact, their consumption is globally increasing in recognition to its nutritional and therapeutic value (SCFFECD, 1999). Therefore, the results obtained for the Green juice indicate that the formulation is also rich in antioxidant compounds like these fruits. 


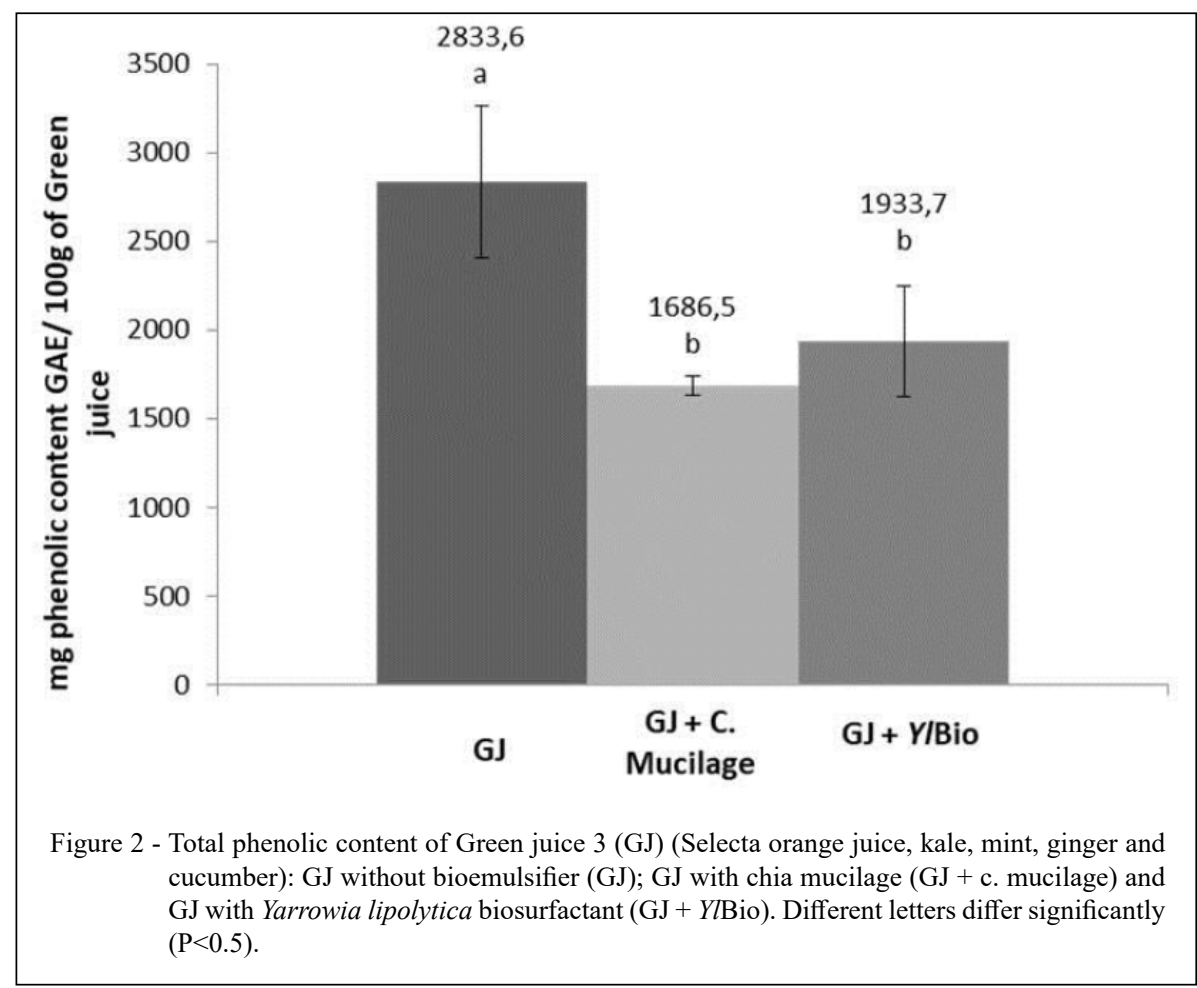

\section{Stability of green juice}

After $24 \mathrm{~h}$ under refrigeration, the Green juice with $2 \mathrm{mg} / \mathrm{ml}$ of chia gel remained visually stable. A higher concentration $(3 \mathrm{mg} / \mathrm{mL})$ of this bioemulsifier caused a gelatinous appearance, not appreciated for a beverage. However, YlBio or xanthan gum weren't able to stabilize the juice during storage at $8{ }^{\circ} \mathrm{C}$. The concentrations used were the CMC (Critic Micellar Concentration) value for $Y l$ Bio and for xanthan gum $(0.5 \mathrm{mg} / \mathrm{mL}$ and 0.3 $\mathrm{mg} / \mathrm{mL}$, respectively). Therefore, the concentrations used for these bioemulsifiers were not enough. Additionally, the $\mathrm{pH}$ of the Green juice is below the optimum $\mathrm{pH}$ range for $Y l$ Bio $(5-7)$ biosurfactant (FONTES et al., 2012).

In order to evaluate quantitatively the stability of the Green juice, the decantation index (D.I.) was measured (Table 3). Xanthan gum presented a high D.I. in comparison to chia gel, indicating that this compound was not able to stabilize the Green juice for all tested concentrations, with no significate difference between them. The YlBio showed a D.I. similar to xanthan gum for 1 and $3 \mathrm{mg} / \mathrm{mL}$ (40.62 and 38.87\%). However, a lower index was reported for $2 \mathrm{mg} / \mathrm{mL}$ (28.59\%) for this bioemulsifier, indicating that there might be an optimum concentration for its performance.

It is possible to observe that for chia gel (Table 3) the higher the concentration, the higher the D.I. of Green juice. Although, chia gel production efficiency was low it was the best bioemulsifier tested. For $3 \mathrm{mg} / \mathrm{mL}$ the formation of a liquid column was not observed, but as mentioned the appearance was not good. Therefore, the best concentration reported for chia gel was $2 \mathrm{mg} / \mathrm{mL}$.

\section{Rheological behavior of green juice}

The rheological behavior of fruit liquid products is influenced by the concentration, chemical composition, size, shape and arrangement of the particles that composed the dispersed phase because they are composed by solid particles dispersed in an aqueous phase. Most fluid food do not have the simple Newtonian rheological model; and therefore, more complex models are used to describe their behavior, such as the Power Law (Ostwald-de-Waele), the Casson, the Mizrahi-Berk, the Herschel-Bulkley and Bingham (PELEGRINE et al. 2012).

Figure 3 shows shear stress as a function of shear rate for the filtered Green juice 3 with 
Table 3 - Decantation Index for the Green juice 3 (Selecta orange juice, kale, mint, ginger and cucumber) with Yarrowia lipolytica biosurfactant $(Y l \mathrm{Bio})$, chia gel and xanthan gum in different concentrations.

\begin{tabular}{lccc}
\hline Bioemulsifiers & & & \\
& & & \\
& $1 \mathrm{mg} / \mathrm{mL}$ & $\mathrm{mg} / \mathrm{mL}$ & $3 \mathrm{mg} / \mathrm{mL}$ \\
YlBio & $40.62 \pm 0.24^{\mathrm{a}}$ & $28.59 \pm 0.08^{\mathrm{b}}$ & $38.87 \pm 0.11^{\mathrm{a}}$ \\
chia gel & $20.33 \pm 0.04^{\mathrm{a}}$ & $4.60 \pm 0.25^{\mathrm{c}}$ & $0.00 \pm 0.00^{\mathrm{c}}$ \\
xanthan gum & $38.74 \pm 0.02^{\mathrm{a}}$ & $40.06 \pm 0.19^{\mathrm{a}}$ & $37.14 \pm 0.12^{\mathrm{a}}$ \\
\hline
\end{tabular}

"Juice height in the tube/ liquid column formed in $24 \mathrm{~h}$ (in $\mathrm{cm}$ ) $\mathrm{x} 100$. Different letters differ significantly ( $<0.5$ ). Average from triplicates.

and without the bioemulsifiers $Y l$ Bio and chia gel. A linear tendency is observed for all samples in comparison to the profile of whole pulp juices shown by PELEGRINE et al. (2012). However, table 4 shows that the Newton model (linear model) wasn't the best model to fit experimental data for all samples. Therefore, to determine the rheological behavior of the juices, other models were taken in consideration. High values of correlation coefficient $\left(\mathrm{R}^{2}\right)$ were reported for all models, including the
Newtonian, but Mizhari-Berk presented the higher values for most samples. The Power Law and the Mizhari-Berk index $\mathrm{n}$ indicates the pseudoplastic behavior of the juices, since they are less than unity (VANDRESEN et al., 2009), except for the pure Green juice that shows a Newtonian behavior ( $\mathrm{n}$ 1 for Mizhari-Berk model). Pseudoplastic behavior are typical for fruit (PELEGRINE et al., 2002) or vegetable (VANDRESEN et al., 2009) juices because of the presence of insoluble solids. This indicated that the juice without the bioemulsifiers tend to behave as

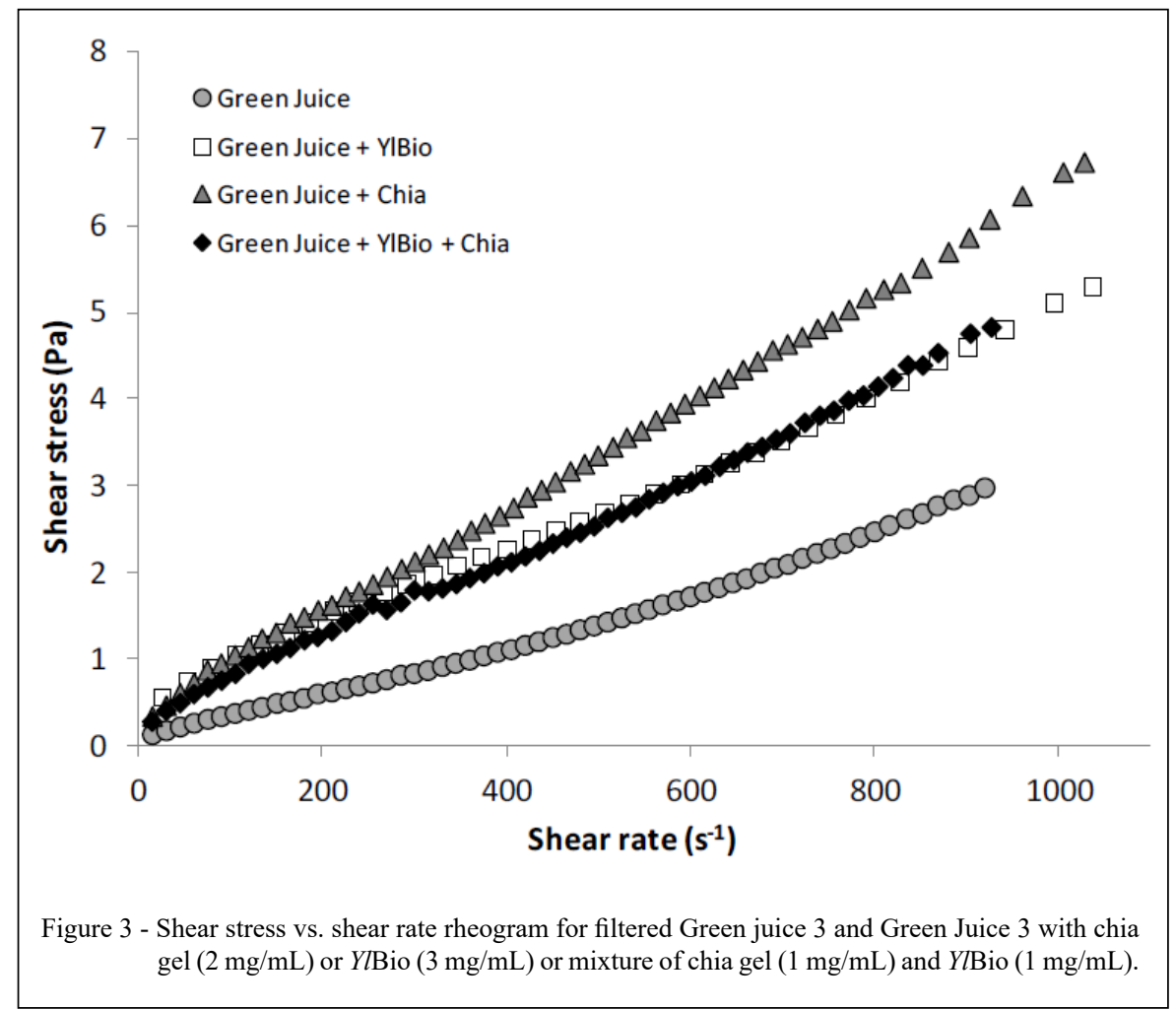

Ciência Rural, v.50, n.3, 2020. 
Table 4 - Rheological parameters of the filtered Green Juice 3 and Green Juice 3 with chia gel $(2 \mathrm{mg} / \mathrm{mL})$ or $Y l \mathrm{Bio}(3 \mathrm{mg} / \mathrm{mL})$ or mixture of chia gel $(1 \mathrm{mg} / \mathrm{mL})$ and $Y l \mathrm{Bio}(1 \mathrm{mg} / \mathrm{mL})$ obtained by fitting the experimental data to the rheological models.

\begin{tabular}{|c|c|c|c|c|}
\hline \multirow{2}{*}{$\begin{array}{l}\text { Rheological Models } \\
\text { Newton: } \tau=\mu(\gamma)\end{array}$} & \multicolumn{4}{|c|}{ 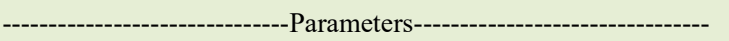 } \\
\hline & $\mu$ & & & $\mathrm{R}^{2}$ \\
\hline Green Juice & 0.00306 & & & 0.9863 \\
\hline Green Juice + chia mucilage & 0.00636 & & & 0.9969 \\
\hline Green Juice $+Y l$ Bio & 0.00516 & & & 0.9840 \\
\hline Green Juice + chia mucilage $+Y l$ Bio & 0.00540 & & & 0.9851 \\
\hline Ostwald-De-Waele: $\tau=k(\gamma)^{\mathrm{n}}$ & $k$ & $\mathrm{n}$ & & \\
\hline Green Juice & 0.0020 & 1.063 & & 0.9936 \\
\hline Green Juice + chia mucilage & 0.0139 & 0.891 & & 0.9967 \\
\hline Green Juice $+Y l$ Bio & 0.0175 & 0.817 & & 0.9838 \\
\hline Green Juice + chia mucilage $+Y l$ Bio & 0.0145 & 0.848 & & 0.9902 \\
\hline Bingham: $\tau=\tau 0+\eta_{\infty} \gamma$ & $\tau_{0}$ & $\eta_{\infty}$ & & \\
\hline Green Juice & -0.166 & 0.00332 & & 0.9934 \\
\hline Green Juice + chia mucilage & 0.315 & 0.00628 & & 0.9993 \\
\hline Green Juice $+Y l$ Bio & 0.393 & 0.00468 & & 0.9958 \\
\hline Green Juice + chia mucilage $+Y l$ Bio & 0.307 & 0.00493 & & 0.9960 \\
\hline Casson: $\tau^{0.5}=k_{\mathrm{OC}}+k_{\mathrm{C}} \gamma^{1 / 2}$ & $k_{\mathrm{OC}}$ & $k_{\mathrm{C}}$ & & \\
\hline Green Juice & -0.105 & 0.0593 & & 0.9941 \\
\hline Green Juice + chia mucilage & 0.183 & 0.0751 & & 0.9989 \\
\hline Green Juice $+Y l$ Bio & 0.266 & 0.0626 & & 0.9927 \\
\hline Green Juice + chia mucilage $+Y l$ Bio & 0.216 & 0.0650 & & 0.9941 \\
\hline Mizhari-Berk: $\tau^{0.5}=k_{\mathrm{OM}}+k_{\mathrm{M}} \gamma^{\mathrm{nM}}$ & $k_{\mathrm{OM}}$ & $k_{\mathrm{M}}$ & $\mathrm{n}_{\mathrm{M}}$ & \\
\hline Green Juice & 0.497 & 0.00211 & 0.935 & 0.9999 \\
\hline Green Juice + chia mucilage & 0.807 & 0.00726 & 0.800 & 0.9984 \\
\hline Green Juice $+Y l B$ io & 0.865 & 0.00461 & 0.825 & 0.9986 \\
\hline Green Juice + chia mucilage $+Y l$ Bio & 0.819 & 0.00398 & 0.869 & 0.9996 \\
\hline
\end{tabular}

$k, k_{\mathrm{C}}$ consistency indices $\left(\mathrm{Pa} \mathrm{s}^{\mathrm{n}}\right), k_{\mathrm{M}}$ consistency index $\left(\mathrm{Pa}^{1 / 2} \mathrm{~s}^{\mathrm{n}}\right), k_{\mathrm{OC}}$ yield stress $(\mathrm{Pa}), k_{\mathrm{OM}}$ square root of the yield stress $(\mathrm{Pa} 1 / 2)$, $\mathrm{n}, \mathrm{n}_{\mathrm{M}}$ fluid behavior indices (dimensionless), $\eta_{\infty}$ consistency index (Pa sn), $\gamma$ shear rate $\left(\mathrm{s}^{-1}\right), \tau$ shear stress $(\mathrm{Pa}), \tau_{0}$ yield stress $(\mathrm{Pa}), \mu$ viscosity (Pa s).

a Newtonian fluid because its suspended particles decantat. The presence of the bioemulsifiers increase the consistency of the Green juice as the consistency indices $\left(k, k_{\mathrm{C}}\right)$ and consistency index $\left(k_{\mathrm{M}}\right)$ shows.

\section{CONCLUSION}

The best green juice formulation, Selecta sweet orange juice (Citrus sinensis L.), kale (Brassica oleracea), mint (Mentha s.p.), ginger (Zingiber officinale) and cucumber (Cucumis sativus), presented a high content of Total Phenolic Compounds and Total Antioxidant Capacity, close to tropical Brazilian fruits extracts with high and known antioxidant activity, Açaí and Umbu. It was reported a low reducing sugar content and low energy value, which indicated its use for low calorie diet, but it is not advisable to replace a meal since it does not have enough carbohydrates or proteins for an adult. Despite being increasingly used for healthy aspects, Green juices properties are not yet studied or reported. Results present in this manuscript bring new insights for the introduction of Green juices in human diet. Chia gel was able to maintain a homogeneous characteristic for the Green juice formulation reducing the decantation index promoting physical integrity to beverage. The biosurfactant produced by Yarrowia lipolytica (YlBio) also reduced the D.I. with concentration of $2 \mathrm{mg} / \mathrm{mL}$. The non-synthetic surfactants tested are potential compounds to be used to stabilize food preparations and more specifically liquid formulations like juices. The Green juice presents a rheological behavior as a Newtonian fluid and with the bioemulsifiers ( $Y l$ Bio and chia gel) it changed a bit to Pseudoplastic due to the stabilization effect of these compounds.

\section{ACKNOWLEDGEMENTS}

The authors thanks financial support from Fundação Carlos Chagas Filho de Amparo à Pesquisa do Estado do Rio De 
Janeiro (FAPERJ) and Conselho Nacional de Desenvolvimento Científico e Tecnológico (CNPQ) (Brazil). Thanks for laboratório de Engenharia Química da Escola de Química (LADEQ- EQUFRJ) for the rheological analyzes and for Coordenação de Aperfeiçoamento de Pessoal de Nível Superior (CAPES) (Brazil) with Finance code 001 for financed in part this research.

\section{DECLARATION OF CONFLICT OF} INTERESTS

The authors declare no conflict of interest. The founding sponsors had no role in the design of the study; in the collection, analyses, or interpretation of data; in the writing of the manuscript, and in the decision to publish the results.

\section{AUTHORS' CONTRIBUTIONS}

All authors contributed equally for the conception and writing of the manuscript. All authors critically revised the manuscript and approved of the final version.

\section{REFERENCES}

ADOLF LUTZ INSTITUTE. Physical Chemical methods for Food. 4. ed. Brasília: Ministry of Health. (2008). Available from: $<\mathrm{http} / / /$ www.ial.sp.gov.br/resources/editorinplace/ial/2016_3_19/ analisedealimentosial_2008.pdf $>$. Accessed: Jul. 25, 2015 . (Electronic publication).

AGUILAR, K., et al. Effect of UV-Vis irradiation on enzymatic activities and the physicochemical properties of nectarine juices from different varieties. LWT - Food Science and Technology, (65), 969-977. (2016). doi: 10.1016/j.1wt.2015.09.006.

AMARAL, P. F. F., et al. Production and characterization of a bioemulsifier from Yarrowia lipolytica. Process Biochemistry, 41(8), 1894-1898, (2006). doi: 10.1016/j.procbio.2006.03.029

ASSOCIATION OF OFFICIAL ANALYTICAL CHEMISTS - AOAC, 2012. Official method 920.177. Rockville: AOAC International. Available from: <https://ci.nii.ac.jp/ naid/20001310621/>. Accessed: Mar. 22, 2015. (Electronic publication).

ARTS, I. C. \& HOLLMAN, P. C. Polyphenols and disease risk in epidemiologic studies, (2005). American Journal of Clinical Nutrition, 81 (1), 317S-325S. doi: 10.1093/ajcn/81.1.317S. BARTH, G. AND GAILLARDIN, C. Physiology and genetics of the dimorphic fungus Yarrowia lipolytica. FEMS Microbiol, 19, (4), 219-37, (1997). doi: 10.1111/j.1574-6976.1997.tb00299.x.

BAŞKAN, K. S., et al. Spectrophotometric total reducing sugars assay based on cupric reduction. Talanta, 147, 162-168, (2016). doi: $10.1016 /$ j.talanta.2015.09.049.

BLIGH, E.G. AND DYER, W. J. A rapid method for total lipid extraction and purification, Canadian Journal of Biochemistry and Physiology, 37, 911-917, (1959).

BONOLI, M., et al. Antioxidant phenols in barley (Hordeum vulgare L.) flour: comparative spectrophotometric study among extraction methods of free and bound phenolic compounds. Journal of Agricultural and Food Chemistry, 11, 52, (16), 5195200, (2004). doi: 10.1021/jf040075c.
COELHO, M. S., AND SALAS-MELLADO, M. M. Effects of substituting chia (Salvia hispanica $\mathrm{L}$.) flour or seeds for wheat flour on the quality of the bread. LWT-Food Science and Technology. 60, (2),729-736, (2015). doi: 10.1155/2017/7352631.

FRANKE, A. A., et al. Vitamin $\mathrm{C}$ and flavonoid levels of fruits and vegetables consumed in Hawaii. Journal of Food Composition and Analysis. 17, 1-35, (2004). doi:10.1016/S08891575(03)00066-8.

FONTES, G. C., et al. Renewable resources for biosurfactant production by Yarrowia lipolytica, Brazilian Journal of Chemical Engineering, 29 (03), 483 - 493, (2012). doi: 10.1590/ S0104-66322012000300005.

FOOD AND AGRICULTURE ORGANIZATION OF THE UNITED NATIONS (FAO),. Food Energy - Methods of Analysis and Conversion Factors. Report of a technical workshop. Rome. (2003). Available from: $<\mathrm{http}: / /$ www.fao.org/3/Y5022E/Y5022E00. htm>. Accessed: Apr. 23, 2015. (Electronic publication).

GRUNERT, K.G. European consumers' acceptance of functional foods. Annals of the New York Academy of Sciences, 1190, 166173, (2010). doi: 10.1111/j.1749-6632.2009.05260.x.

HALLIWELL, B. AND GUTTERIDGE, J.C. The definition and measurement of antioxidants in biological systems. Free Radical Biology and Medicine, 18, 125-126, (1995). doi:10.1016/08915849(95)91457-3.

HENNEKENS, C.H. Platelet inhibitors and antioxidant vitamins in cardiovascular disease. American Heart Journal. 128, 13331336, (1994). doi: 10.1016/0002-8703(94)90256-9.

TRUMBO, et al. Dietary Reference Intakes for Energy, Carbohydrate, Fiber, Fat, Fatty Acids, Cholesterol, Protein and Amino Acids. Journal of the American Dietetic Association, 102(11), 1621-1630, 2002. doi:10.1016/s0002-8223(02)90346-9.

KUSKOSKI, E.M., et al. Aplicatíon de diversos métodos químicos para determinar actividad antioxidante en pulpa de frutos. Ciência e Tecnologia de Alimentos, 25, (4), 726-732, (2005). doi: 10.1590/ S0101-20612005000400016.

MUÑOZ, L.A., et al. Chia seeds: Microstructure, gel extraction and hydration. Journal of Food Engineering. 108, 216-224, 2012. doi: $10.1590 / 1981-6723.1814$.

MUTHUSAMY, K., et al. Biosurfactants: Properties, commercial production and application. Current Science, 94, 736-747, (2008). doi: 10.3923/jm.2015.181.192.

PALA, C..U. and TOKLUCU, A. K, Microbial, physicochemical and sensory properties of UV-C processed orange juice and its microbial stability during refrigerated storage. LWT - Food Science and Technology, 50, 426-431, (2013). doi: 10.1016/j. lwt.2012.09.001.

PELEGRINE, D. H., F. C. et al. Rheological behavior of pineapple and mango pulps. LWT-Food Science and Technology, 35 (8), 645-648, 2012. doi: 10.1006/fstl.2002.0920.

PIMENTEL, T. C., et al. Probiotic viability, physicochemical characteristics and acceptability during refrigerated storage of clarified apple juice supplemented with Lactobacillus paracasei ssp. paracasei and oligofructose in different package type. LWT

Ciência Rural, v.50, n.3, 2020. 
Food Science and Technology, 63, 415-422,2015. doi: 10.1016/j. lwt.2015.03.009.

PINELI, L. L. O., et al. Antioxidants and other chemical and physical characteristics of two strawberry cultivars at different ripeness stages. Journal of Food Composition and Analysis, 24 11, 2011doi: 10.1016/j.jfca.2010.05.004.

PULIDO, R., et al. Antioxidant activity of dietary as determined by a modified ferric reducing/ antioxidant power assay. Journal Agriculture and Food Chemistry, 48, 3396-3402,2000. doi: $10.1021 /$ jf9913458.

ROMANO, K. R., et al. How do Brazilian consumers perceive a non-traditional and innovative fruit juice? An approach looking at the packaging. Food Research International, 74, 123-130,2015. doi: $10.1016 /$ j.foodres.2015.04.033

RUFINO, M. S. M., et al. Bioactive compounds and antioxidant capacities of 18 non-traditional tropical fruits from Brazil. Food Chemistry, 121, 996-1002, 2010. doi:10.1016/j. foodchem.2010.01.037.

SPADA, J. C., et al. Physical, chemical and sensory characterization of soy-based desserts made with chia gel. Ciência Rural, Santa Maria, 44, (2), 374-379,2014. doi: 10.1590/S010384782014000200029.

Scientific Concepts of Functional Foods in Europe Consensus Document, (SCFFECD). British Journal of Nutrition, 81(4), S1S27,1999. doi:10.1017/S0007114599000471.

Scheffers, F., et al. Pure fruit juice and fruit consumption and the risk of CVD: The European Prospective Investigation into
Cancer and Nutrition-Netherlands (EPIC-NL) study. British Journal of Nutrition, 121(3), 351-359, 2019. doi:10.1017/ S0007114518003380.

NEPA - UNICAMP. Tabela Brasileira de Composição de Alimentos. 4. ed. revisada e ampliada, Campinas: NEPAUNICAMP, 2011. 161 p. Available from: <http://www.nepa. unicamp.br/taco/tabela.php?ativo $=$ tabela $>$ Accessed: May, 21, 2015. (Electronic publication).

TIBURSKI, J. H. Nutritional properties of yellow mombin (Spondias mombin L.) pulp. Food Research International, 44, 2326-2331,2011. doi:10.1016/j.foodres.2011.03.037.

TRINDADE, J. R., et al. Aging mechanisms of oil-in-water emulsions based on a bioemulsifier produced by Yarrowia lipolytica. Colloids and Surfaces A: physicochemical and engineering aspects, 324(1-3), 149-154, 2008.

WAIN, T. AND HILLS, W. E. The phenolic constituents of Punnus domestica. I-quantitative analysis of phenolic constituents. Journal Science of Food Agricutural, London. 19, 63-68,1995. doi: $10.1002 /$ jsfa. 2740100110 .

VANDRESEN, et al. Temperature effect on the rheological behavior of carrot juices, Journal of Food Engineering, 92, (3), 269-274,2009. doi: 10.1590/1981-6723.0915.

ZULUETA, A., et al. Vitamin C, vitamin A, phenolic compounds and total antioxidant capacity of new fruit juice and skim milk mixture beverages marketed in Spain. Food Chemistry, 103(4), 1365-1374,2007.doi: 10.1016/j.foodchem.2006.10.052 